Chapter 4

\title{
The GIS Project for the Geologic Assessment of Undiscovered Oil and Gas in the Upper Cretaceous Navarro and Taylor Groups, Western Gulf Province, Texas
}

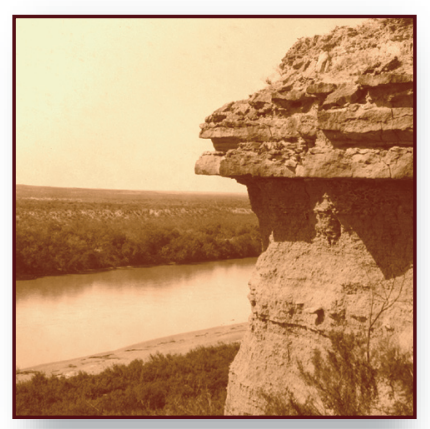

Click here to return to Volume Title Page

By Laura R.H. Biewick

Chapter 4 of

Petroleum Systems and Geologic Assessment of Undiscovered Oil and Gas, Navarro and Taylor Groups, Western Gulf Province, Texas

By U.S. Geological Survey Western Gulf Province Assessment Team

U.S. Geological Survey Digital Data Series DDS-69-H 


\section{U.S. Department of the Interior \\ P. Lynn Scarlett, Acting Secretary}

\section{U.S. Geological Survey P. Patrick Leahy, Acting Director}

U.S. Geological Survey, Reston, Virginia: 2006

For product and ordering information:

World Wide Web: http://www.usgs.gov/pubprod

Telephone: 1-888-ASK-USGS

For more information on the USGS — the Federal source for science about the Earth, its natural and living resources, natural hazards, and the environment:

World Wide Web: http://www.usgs.gov

Telephone:1-888-ASK-USGS

Any use of trade, product, or firm names is for descriptive purposes only and does not imply endorsement by the U.S. Government.

Although this report is in the public domain, permission must be secured from the individual copyright owners to reproduce any copyrighted materials contained within this report.

Suggested citation:

Biewick, L.R.H., 2006, The GIS project for the geologic assessment of undiscovered oil and gas in the Upper Cretaceous Navarro and Taylor Groups, Western Gulf Province, Texas: U.S. Geological Survey Digital Data Series DDS-69-H, Chapter 4, 1 p. 


\title{
The GIS Project for the Geologic Assessment of Undiscovered Oil and Gas in the Upper Cretaceous Navarro and Taylor Groups, Western Gulf Province, Texas
}

\author{
By Laura R.H. Biewick
}

A geographic information system (GIS) focusing on the Upper Cretaceous Navarro and Taylor Groups in the Gulf Coast region was developed as a visual-analysis tool for the U.S. Geological Survey's 2003 assessment of undiscovered, technically recoverable oil and natural gas resources in the Western Gulf Province. The Central Energy Resources Team of the U.S. Geological Survey has also developed an Internet Map Service to deliver the GIS data to the general public. This mapping tool utilizes information from a database about the oil and natural gas endowment of the United Statesincluding physical locations of geologic and geographic data - and converts the data into visual layers. Portrayal and analysis of geologic features on an interactive map provide an excellent tool for understanding domestic oil and gas resources for strategic planning, formulating economic and energy policies, evaluating lands under the purview of the Federal Government, and developing sound environmental policies. Assessment results can be viewed and analyzed or downloaded from the internet web site.

Hydrocarbon assessment-unit boundaries include the assessment results as attributes. Specialized maps, which we in the Central Energy Resources Team refer to as "cell maps," illustrate the degree of exploration and the type and distribution of production for each assessment unit. Other data that are also available in the interactive map include the following:

- Cities

- Roads

- Geologic provinces

- Total petroleum system

- States

- Counties

- Public land survey system

- Streams and water bodies

- Federal surface ownership

- Shaded relief
Click on the map to access the Western Gulf Province Internet Map Service.

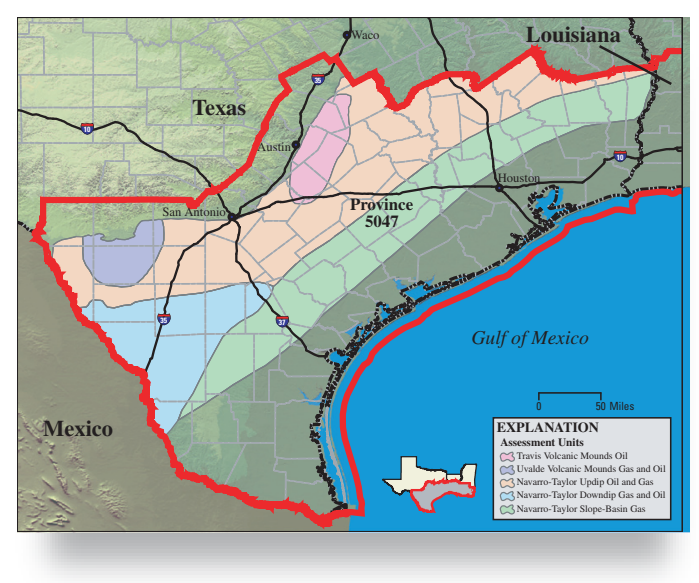

The spatial data that formed the basis of the GIS for the Navarro and Taylor Groups are provided online at the USGS National Oil and Gas Assessment web site (NOGA Online: http://energy.cr.usgs.gov/oilgas/noga/) and are also contained on this CD-ROM in the Spatial folder. Several data formats are provided as noted by subfolders (Shape and Export). The Doc folder contains metadata documentation in HTML format that is also incorporated in each shapefile and export file in XML format.

Most of the base cartographic data layers used in the GIS project were obtained from the U.S. Department of the Interior National Atlas website, www.nationalatlas.gov, or the U.S. Geological Survey National Map, http://nmviewogc.cr.usgs. gov/viewer.htm.

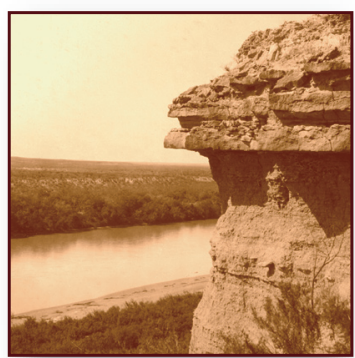

Click here to return to Volume Title Page 